Bulletin de la Société Royale des Sciences de Liège, Vol. 85, 2016, p. 1378 - 1391

\title{
The urban design guideline and conceptual model development for improving the quality of visual appeal of pedestrian; Mashhad Monfared Street Pedestrian
}

\author{
Morteza Mirgholami $^{1}$, Seyede Farzaneh TABAtabaei ${ }^{2, *}$, Parisa Hashempour ${ }^{3}$
}

${ }^{1}$ Dean of Architecture and Urban Planning Faculty, PhD of Urban Design and Professor

Assistant in Tabriz Islamic Art University

${ }^{2}$ Master student of Urban Design in Tabriz Islamic Art University

${ }^{3}$ Deputy of Architecture and Urban Planning Faculty, PhD of Architecture and Professor

Assistant in Tabriz Islamic Art University

*Corresponding author: Tabatabaei244@gmail.com

\begin{abstract}
According to the formation of initial steps in urban pedestrian design of Iran, this study tries to prepare visual-spatial quality measurement framework for urban pedestrians to evaluate the quality of visual appeal of pedestrians and on the other hand it provides the promotion of their visual quality and effective use in the next experiences. in this regard and on the basis of comparative comparison and according to the principle of interment understanding of experts and scholars opinions, this study analyzes the related theoretical foundations and develops a special conceptual model to evaluate visual appeal of pedestrians. Designing for pedestrians requires more attention than designing for vehicles on the other hand, perhaps the most problematic criterion of walkability that is less discussed is visual-spatial quality. this study that has practical aspects, develops model and components of pedestrians visual appeal by analyzing theoretical documents and studies and then assess the situation of the study area -Mashhad Monfared street- based on theoretical framework and finally, it offers a designing guideline to improve visual appeal of Monfared pedestrian.
\end{abstract}

Keywords: walkability, visual appeal, urban design guideline, conceptual model, Mashhad Monfared street.

\section{Introduction}

Cities and peoples' lives changed with the invention and increasing production of cars. Urban spaces that were defined based on human scale and according to slow movement and level of understanding of pedestrian, now are designed based on vehicle scale and according to rapid movement and level of understanding from inside of them. Human being was gradually faded as the main user of urban spaces and his need for peace in the city was ignored. Thus the absence of people in the city as pedestrian would mean the loss of civic sense and loss of quality, vibrancy and joyfulness. Therefore in order to maintain such urban features, pedestrians and proper walking spaces should be considered especially. It is a long time that walk development movement and allocation of walking spaces to pedestrians in the city have find their places in major urban projects of developed countries and improving the quality of these spaces, especially visual appeal quality is considered as the main purpose of this article. Due to lack of quality 
measurement, pedestrian design is merely limited to motion control of vehicles and basic actions and special potentials of pedestrian, especially in the field of spatial-visual are not used to create a vibrant public space. With this approach, this study attempts to develop a special model to evaluate the visual appeal of pedestrian by examining related theoretical foundations and evaluates the study area according to that model and finally offers proposed strategies in the form of urban design guidelines and on the other provides the basis of positive use in next experiences.

\section{Research methods}

In this study after understanding the necessity of pedestrian construction and providing definition and examining spatial-visual fields of walking spaces, focus is on providing quality components of visual appeal for optimal designing of such urban spaces. Therefore, at first the theoretical foundations of spatial-visual quality of urban walking spaces were studied, then valuable criteria of walking spaces visual appeal were selected by corresponding visual appeal criteria and the nature of pedestrian as an urban space, after that, the mentioned criteria and indicators are presented in the form of special conceptual model, then by evaluating the situation of the study area -Mashhad Monfared Street- and analyzing it based on the model and SWAT qualitative method, main solutions and criteria were developed to improve the visual appeal of Monfared pedestrian in the form of urban design guideline.

\section{History and Theoretical Foundation of Research}

Experience of urban spaces is an activity that involves motion and time, major part of city's visual design is experience of motion in space [2]. Generally the history of footpath goes back to the region of Julius Cesar in Rome. Since the streets were over crowded he had to prevent the transition of chariots in the city at daylight, except chariots for construction and government [3]. Also one of the first steps in separating the movement of mounted and dismounted was performed in 1858 by Olmsted, American architect and urban planner, in designing New York Central Park. He built a stone bridge on the roadway to cross the pedestrians. After that walking was so widespread that walkability has become the main principal of contemporary movementsnew urban planning- and also urban guidance document put this issue on top of its goals. Efforts to improve the quality of walking spaces are now in such way that these spaces are used as tourist attracting places. Walking spaces such as London Trafalgar Square as one of the four tourist attracting places in the world and the role of walking spaces in urban vitality and health, reveals clearly planning and designing to develop and improve the quality especially spatialvisual attractiveness of these spaces. It can be said that an important step after necessity of the formation of footpaths is trying to improve their spatial- visual quality.

Walkability, means the ability of one place to walk [4]. Cowan (1388) defines walkability such: convenience with something that creates possibility of a stroll around the area, from one point to another, or from house to local facilities. Cases where problematic for this motion are impassable roads and spacious streets that are low possibility of cross them [4]. South worth (2005) by raising this question what is walkability? Expresses it is quality that been very referred but less defined and expresses that if we want to design the walkable city it should define and express in the form of functional criteria. So offers the definition for walkable environment: walkable environment is an area that the built environment supported walking and encourages to it by 
providing comfort and safety of pedestrians, and provides the people relationship of the numerous destinations with acceptable and reasonable time and effort and offers visually appealing qualities along the path [6].

In urban design, discussion of "Quality" is considerable both from the aspect of "practical" and "theoretical. The etymological meaning of "quality" in the dictionary of the Amid Persian language is expressed how, modal, state and trait anything [7]. The Oxford English Dictionary also provides four meanings for quality: degree of goodness and value of things, Goodness and Perfection in a general sense, traits and peculiarities and special aspects and characteristic symptoms. The ambiguous meaning and complex nature of the concept of "quality" and diverse deemed people in it, been causing the dispersion and lack of coherence in the viewpoints provided [8]. With the start of the present century, the quality concept scope finds its place to the extent that various institutions relying on this issue to assess the city's public spaces. Provides disposal a diverse range of criteria, search between the provided comments on quality by experts and institutions. However can be summarized the most important things that have more proximity conceptual to walkable subject in table 1.

Table 1: Provided quality factors of sight of specialists and institutions; Source: author

\begin{tabular}{|c|c|c|}
\hline Intellectuals & Book - Article -Report & factors \\
\hline $\begin{array}{l}\text { Jacobs, Jane(Jane } \\
\text { Butzner) }\end{array}$ & $\begin{array}{l}\text { "The Death and Life of Great } \\
\text { American Cities", } 1961\end{array}$ & $\begin{array}{l}\text { pay attention to activities, use mixing , Permeability and accessibility, } \\
\text { flexibility, }\end{array}$ \\
\hline Kevin A. Lynch & The Image of the City, 1981 & Vitality, Meaning, Compatibility,_accessibility, Control , efficiency, Justice \\
\hline Vilolich. F & $\begin{array}{l}\text { The reading city and small urban } \\
\text { places design, } 1983\end{array}$ & $\begin{array}{l}\text { Readability of environment, Freedom of choice, Motivated by the use of } \\
\text { contrasting forms, The possibility of social life, pay attention to Indigenous } \\
\text { bonds, }\end{array}$ \\
\hline Bentley, Ian. Et al & $\begin{array}{l}\text { "responsive environment" and } \\
\text { Reforms article, } 1990\end{array}$ & $\begin{array}{l}\text { Permeability, Variety, legibility , flexibility, Visual compatibility, Richness, } \\
\text { Sense of belonging, energy efficiency, Cleaning, Maintenance and protection } \\
\text { of ecosystems }\end{array}$ \\
\hline $\begin{array}{l}\text { Southworth, } \\
\text { Michael }\end{array}$ & $\begin{array}{l}70 \text { Cases and paper "theory and } \\
\text { practice of contemporary urban } \\
\text { design", } 1989\end{array}$ & $\begin{array}{l}\text { Structure and legibility, Form, Comfort and Convenience, accessibility, } \\
\text { Health and safety, Historic Preservation, Vitality, Protecting the natural } \\
\text { environment, Variety, Compatibility, expanse, Social intercourse, Equality, } \\
\text { Maintenance, Versatility, meaning, Supervision, the Sense of Place, Identity, } \\
\text { the Views and Sights, the Human scale }\end{array}$ \\
\hline Nelessen, A. C & $\begin{array}{l}\text { Perspectives for a New American } \\
\text { Dream,1994 }\end{array}$ & $\begin{array}{l}\text { Human Scale, Ecology-based accountability, Promoting pedestrian-oriented, } \\
\text { Prediction open spaces, predicting of Nucleus in the plan, pay attention to } \\
\text { Street's view, Variety, the User mixing. }\end{array}$ \\
\hline $\begin{array}{l}\text { Punter \& } \\
\text { Carmona }\end{array}$ & $\begin{array}{l}\text { Design dimensions of urban } \\
\text { planning, } 1997\end{array}$ & $\begin{array}{l}\text { Environmental sustainability, city’s View, Views, City's form, Form of } \\
\text { buildings, Public sector. }\end{array}$ \\
\hline $\begin{array}{l}\text { Carmona, } \\
\text { Matthew }\end{array}$ & Public places - urban spaces, 2003 & $\begin{array}{l}\text { accessibility, The hard and soft space, The public space, Safety and security, } \\
\text { city's view, Mixing and compaction, Inclusiveness. }\end{array}$ \\
\hline $\begin{array}{l}\text { Special Force } \\
\text { urban issues }\end{array}$ & $\begin{array}{l}\text { Towards an Urban Renaissance, } \\
1999\end{array}$ & $\begin{array}{l}\text { pay attention to site features, Appropriate plan , Light and sound, Campus } \\
\text { layout, Open spaces, Delinquency prevention, Security, Construction diverse } \\
\text { species, Stability, Public sector, accessibility and permeability }\end{array}$ \\
\hline PPS & $\begin{array}{l}\text { The result of a study of more than } \\
1,000 \text { urban space }\end{array}$ & Accessibility and continuity, Comfort and phantasm, activities, Sociability \\
\hline OPDM & By Design, 2000 & $\begin{array}{l}\text { Cleanliness, accessibility , appeal, Convenience, Collectivity, vitality, } \\
\text { performance, Differentiation, Safety and security, Robustness (flexibility) }\end{array}$ \\
\hline
\end{tabular}




\section{Background of Physical-visual walking arenas (Visual Appeal)}

In Small-scale, designed pedestrian zone requires more attention than the design for vehicles. Perhaps most problematic criterions of walkability that fewer discussed below, are physical qualities and Background of path. If we want to encourage and invite to walk, should be look to issues beyond of connection and continuity, land use, security and quality of path. Safe and continuous path with physical body and boring background not preoccupied pedestrians to themselves, and not inviting. The path must sparked interest pedestrians and to involve them their own, many issues related to physical fabric can be correlated with the positive experience walking: visual attractiveness of the built environment street design as a whole, clarity of walls, visibility activities, trees and other landscaping elements, lighting and scenery[6].

\section{Move in space and spatial sequence}

The experience of urban spaces that covers the move and the time, forms much of the dimension of visual urban design, experience movement in space[2].Kalen raised successive views discuss in 1961. He explains how to navigate in space, appear the different landscapes in succession [9].

Movement in urban space, cause to feel the sequential scenes that creates each one of them an experience for the person. Movement and its specifications path, creates the basic structure of these successive experiences. These elements produce the space, to create a harmonious and progressive, when moving the person, offer specified and continuous structure. The space sequence is qualitative requirement a series of urban spaces. Gehl believes that should be avoided from planning of the direct and long walking path. The curved and interrupted streets are more attractive for walking. Furthermore, the twisty streets act better than the direct streets in terms of decrease the impact and interference of the wind [11].

\section{Define space}

Open spaces should be designed positively with clear definition and enclose. Should not be unknown and remaining of other spaces. It would be done through definition of function, identity and form for each space and determining its borders through buildings locating, walls, trees and fences. The best way to do this is prepare the form of background. Building as form and space as background. Trancik offers 5 principle of physical design for creation a coherent urban space:

The first principle, attention to the movement as connecting place: This principle says that outer space should be seems act as a liaison between buildings and guides the power consecutive and sequence with a string of serial spaces.

The second principle, side focus and edges continuity: in Trancik sight in today cities, we should create a new front to public spaces. This work is carried out by filling the empty space that destroy the continuity city walls facing the streets and squares.

The third principle, coherent Bridging: Trancik knows appropriate this principle for when need to prevail the barriers and buffers that reduce the cohesion of the urban texture. Or we correct the remaining spaces between buildings that tarnishing continuity of urban form.

The fourth principle, axis and perspective: according to Trancik, one of the models that could be practical in the existing conditions is observance of hierarchical structure and symmetrical of urban spaces. This organization model can provide visual navigation system for its own that link to each other separate elements of city by help corridors and vision axes. 
The fifth principle: Integration of internal and external space in all urban design projects. It is very important movement between internal and external spaces and the relation between these two spaces, whether viewpoint of the function and whether the visual.

\section{Enclose}

Purpose is limiting a space by its walls, so that human feels is located inside a container. Enclose has a certain degree that at least from two factors of the degree height ratio to floor and comes from the continuity of space wall. In all hard spaces, there are three defining main elements of space. Enclosed space structures, floor and part of the sky sphere that defines roof the most convenient distance for the visual dominance of a building in the equal distance is two times of its height.

\section{Wall continuity (joint skyline)}

Joint sky line, creates continuity and provide define and public arena enclose. Also integrates the new development with existing streets. Minimize retreat buildings increases the capacity of building in connection with public arena. Where buildings sit back from the edge of the adjacent buildings, it should be noted that the remaining space be useful and attractive. The buildings that follow a continuous line around a block of street and contain the interior backyards and courtyard of private space, are more successful than the individual buildings that placed in the middle of a site.

\section{Urban furniture}

Street furniture including an equipment with smaller scale in pavements that causes add scale and activity and human factors to street landscape. Street furniture is a function of performance and necessary and can be part of the purposes of street landscape in community. All too often, the result of unknown ways of urban design, creates disorganization in urban furniture and available equipment that reduces the credit of the city space. Urban furniture can be create quality standards and expectations in a range of different texture areas.

\section{Soft Landscaping}

Soft Landscaping can be a decisive revetment in creation of the character and identity of space. For example oak street is different of pine street. Trees and other vegetation show the change of seasons and create a temporary legibility in urban space. Also they are coverage for urban construction and give a sense of scale to the space. If considered the creation of a formal peace instead dramatic plan, trees may be are in site along straight lines or on the basis of regular geometric designs. Vegetation can determine the identity and function of space. Can give directions or identity, creates enclose or separation. Floor plan and three dimensional of urban space can be enhanced by planting trees. Complete and improve our sense about space container and create the space within other space.

\section{Lighting}

Provide street is as follows lighting in the general lighting in order to create and maintain safety and qualifying for pedestrians and vehicles. Lighting are used to illuminate buildings, sights, passages, parking sites, signs and other exterior spaces besides advertising functions. In addition to the practical applications can considered select the lighting elements among the concerns of design. Provide desirable level of brightness at night is very importance to keep safety the realm 
of pedestrian. For provide the light of vehicles, lampposts are proper, but don't create lighting of the desired of pedestrians. Due to the more slowly move of pedestrians in comparison with people who are riding cars, pedestrians see more details of the environment and stops more and longer and so they need more desperately light. There are three major parts of street lighting. A category light up street, the other group used for pavements, territory of pedestrians and other fixed lighting elements on the boulevards or install on the facade of buildings and the last group are security lighting. Appropriate lighting adds to the safety and also reduces opportunities of crime. A sense of safety affected significantly of brightness. The good lighting and brightness control, in addition to creating positive feelings in pedestrians and drivers have effective role in revealing the dangerous situations.

\section{Conceptual and framework model to enhance the visual appeal of pedestrian}

According to the study of literature review and analysis of theoretical principles in relation to the physical-visual quality of pedestrian and also the requirements in the field such as movement in space, space definition, enclosed, active and continuous walls and ... is necessary that presented special mentioned model for guidance to enhance visual appeal of pedestrian in Iran. Development of factors the visual appeal of pedestrians and conceptual framework design based on this factors requires that the factors be defined. Therefore, factors have been developed based on 1) Goals and the quality of urban design, 2) Literature review, 3) Physical features-visual of pedestrians 4) Factors of visual appeal of pedestrian related to social, Health and Environment values, 5) Based on pedestrian environment quality in urban space level in Iran, which includes the following types:In Figure 1 the factors are expressed in the form of the model.

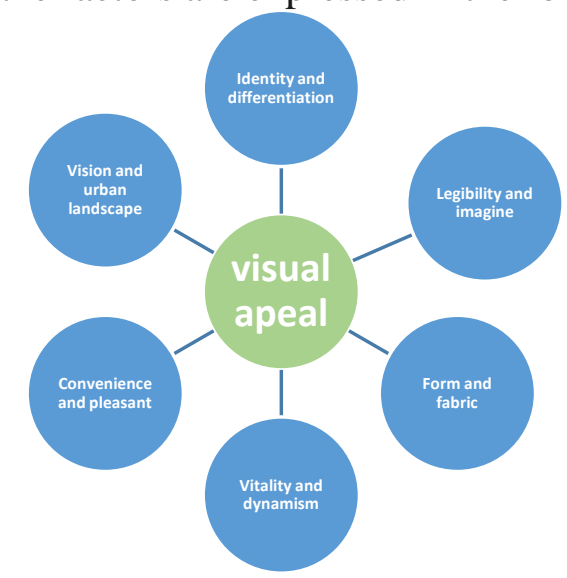

Figure 1: Conceptual Model and indicators to improve the visual appeal of pedestrian environments, source: the author

According to the presentation, now we have reached one of the most important steps of literature review. This step is same build of a reference frame. The theoretical framework is same a window that researcher look at that point of view to phenomenon of case study. Its function is gives direction to research and the other hand provide a link between our research with the structure of existing knowledge and a reflection of the nature of cumulative and summative knowledge. The basic principle that has been considered and it is important in this study is understanding intermental. In this study, with a focus on "Walkability and visual appeal of pedestrians" been tried according to different theories approaches and honorable experts and also with factors, values, and theoretical principles achieved to the wide view and comprehensive in 
relation to the main topic. In figure 2, will be discussed to introduction and presentation of final model.

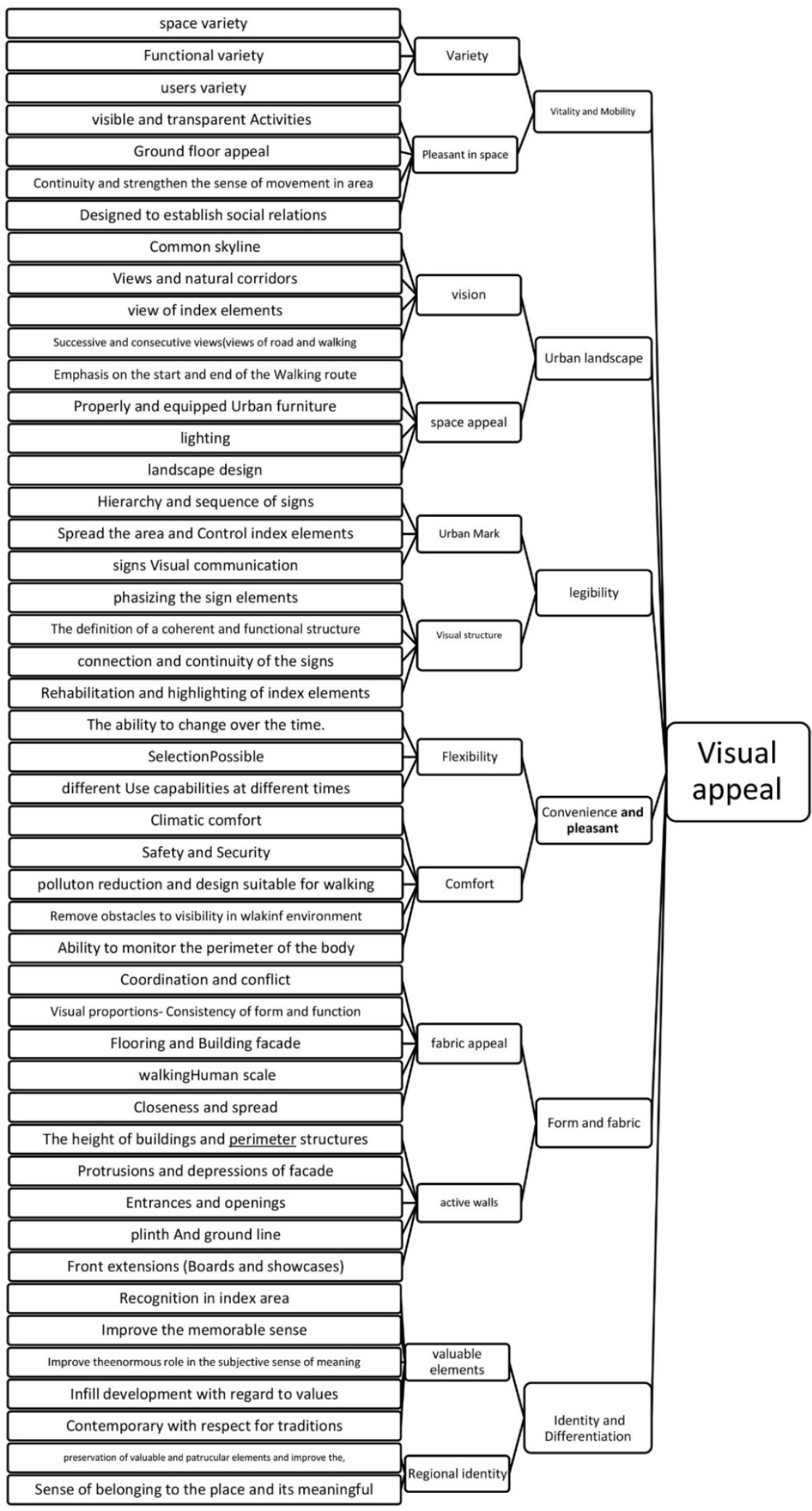

Figure 2: Indexes and factors of improve the visual appeal pedestrian, Source: the author 


\section{Geographical area of the research}

Out geometrically Monfared street is located in the central part of the city that is near the main city node (shohada square ). It is necessary be expressed that the antiquity of Monfared axis means what is known today is due to the Taabodi street, that antiquity of this street back to about fifty to sixty years ago. Forming experience of around texture of Monfared axis is a little more, therefore the Monfared axis is in the mid-city texture of Mashhad which of course is more amenable to the historical texture surrounding the holy shrine

The new texture located in the western area of the city, Monfared axis enclosed among the important streets such as Gharani street, Shahid Motahari boulevard, Taabodi street. Monfared axis arrives from east to Taabodi street and from west to Shahid Motahari boulevard. Gharani street is in the southern neighborhood of this axis. Important note in identifying the location and status of the establishment of Monfared axis is study of its position about to the main structure. Monfared axis has a strong and continuous communication to the main structure of the city.In order to scrutiny of studies and avoid of ambiguity and confusion, determine the study area is required. The areas that are considered part of the study area have been selected according to the most impacts of are associated with the design issue.

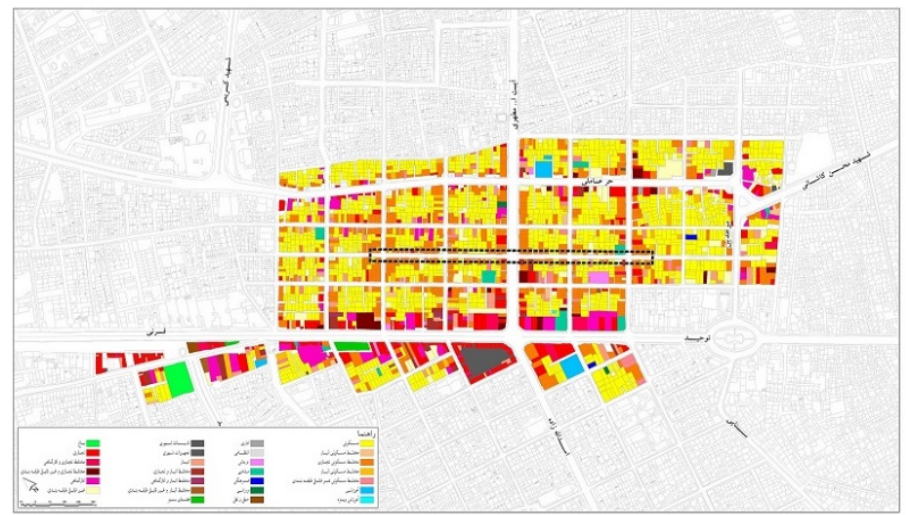

Figure 3: The position of the study area in the metropolitan area

Accordingly, the study area in axle design of Monfared pedestrian, the direct and surrounding tissue of this axis, more precisely is surrounding tissue of 8 and 5 Taabodi street and also surrounding tissue of 4 Motahari street which cover around Monfared axis, Motahari Boulevard with own large width and urban use in its wall has created a strong separation among the direct tissue of eastern Monfared axis, therefore, this area is strongly influenced by Monfared and also the relationship between Monfared and Motahari Boulevard use and the main entrance of Monfared axis is of this Blvd. Taabodi street that determines the eastern border is also the western entrance of Monfared axis. In the wall of this street there are active commercial use which also have infiltrated into the Monfared axis and this part of the tissue has been influenced by Taabodi street. Gharani street has a close relationship with the Monfared in the South with northern wall use, but the south wall is separated from the Monfared axis. Large street width and heavy traffic on that roadway have been the reason of separation of Monfared axis from other sectors. Also most of the entrance accessory of Monfared funded from this area. 


\section{Research findings}

As mentioned in the research method, after physical impressions and provide the relevant Check lists, for the assessment of the conceptual model and operational research in the areea, additional information was collected by a researcher in the field visit. In the following, defined the utility criteria and principles of visual appeal on the whole quite undesirable to quite desirable in the area. After examining the utility of the criteria and principles and relies on three groups of information obtained (Questionnaire, observation and literature review) SWOT matrix was organized for the assessment of the conceptual model. Finally, according to conducted analysis and Assessment, presented suggested strategies and Operational policies.

Table 2: Integrated analysis of the study area based on conceptual model of walkability by qualitative SWOT

\begin{tabular}{|c|c|c|c|c|}
\hline threats & Opportunities & Weaknesses & Strengths & $\begin{array}{c}\text { Visual appeal } \\
\text { indicators }\end{array}$ \\
\hline $\begin{array}{l}\text {.Increase of monotony } \\
\text { in some parts of the axis } \\
\text { and reduction the } \\
\text { diversity of activity and } \\
\text { presence of users and } \\
\text { citizens in space }\end{array}$ & $\begin{array}{l}\text {.The possibility of creating } \\
\text { spatial variation in the area } \\
\text {.The potential of create } \\
\text { diversity of users of the area } \\
\text {.The opportunity of create } \\
\text { transparency and visibility and } \\
\text { attractive on ground floor in the } \\
\text { area } \\
\text {.Possible to design in order to } \\
\text { establish social dealings }\end{array}$ & $\begin{array}{l}\text {.Absence of Spatial variation } \\
\text { in area } \\
\text {.Existence of monotonically } \\
\text { area } \\
\text {.Absence of functional } \\
\text { diversity in Monfared axis }\end{array}$ & $\begin{array}{l}\text {. Existence of absorber use } \\
\text { on the ground floor of } \\
\text { Monfared street and the } \\
\text { surrounding area } \\
\text {. Existence of continuity } \\
\text { and reinforce a sense of } \\
\text { motion in a Monfared space } \\
\text {. Existence of clear and } \\
\text { visibility activities in some } \\
\text { parts of the study area } \\
\text {.The high presence of } \\
\text { people in the study area }\end{array}$ & $\begin{array}{l}\text { Vitality and } \\
\text { dynamism }\end{array}$ \\
\hline $\begin{array}{l}\text { Reduction area space } \\
\text { appeal because of } \\
\text { neglect of the authorities } \\
\text { and residents to } \\
\text { landscaping quality of } \\
\text { Monfared street }\end{array}$ & $\begin{array}{l}\text {.The possibility of creating } \\
\text { appropriate vision to important } \\
\text { and valuable signs. } \\
\text {.The possibility of creating } \\
\text { visual appeal by considering } \\
\text { items such as lighting, street } \\
\text { furniture, inputs and openings } \\
\text { and... } \\
\text {.The possibility of creating an } \\
\text { urban landscape in Gharani and } \\
\text { Motahari axis } \\
\text {.The possibility of creating } \\
\text { visual continuity to the } \\
\text { collection }\end{array}$ & $\begin{array}{l}\text {.Absence of proper and } \\
\text { balanced skyline in the entire } \\
\text { area } \\
\text {.Absence of appropriate } \\
\text { vision to the Index spots } \\
\text {.Absence of emphasis on the } \\
\text { location and the start and end } \\
\text { of the area } \\
\text {.Visual turmoil in the walls } \\
\text {.Pollution of image and urban } \\
\text { landscape } \\
\text {.Lack of attention to the } \\
\text { image of the roof } \\
\text {.Absence of equipped and } \\
\text { appropriate urban furniture in } \\
\text { Monfared street }\end{array}$ & $\begin{array}{l}\text {. Existence of serial vision } \\
\text { in the study area } \\
\text {.Appropriate lighting and } \\
\text { equipped at the study area } \\
\text {.Existence of index } \\
\text { elements and signs in the } \\
\text { area }\end{array}$ & $\begin{array}{l}\text { Vision and } \\
\text { urban } \\
\text { landscape }\end{array}$ \\
\hline $\begin{array}{l}\text {.The loss of coherent } \\
\text { structure and functional } \\
\text { of area } \\
\text {.Reduction the imaging } \\
\text { of the area due to } \\
\text { absence of emphasis on } \\
\text { sign elements }\end{array}$ & $\begin{array}{l}\text {.Possibility of a revival and } \\
\text { sharpens the index } \\
\text { neighborhood elements } \\
\text {.The opportunity to connection } \\
\text { and continuity the signs } \\
\text {.Possible to design appropriate } \\
\text { area by creating continuity } \\
\text { between signs and elements }\end{array}$ & $\begin{array}{l}\text { Absence of hierarchy signs } \\
\text { for the study area visibility } \\
\text {.Absence of open space to } \\
\text { pause and breathing space in } \\
\text { parts of the area } \\
\text {.Absence of signs visual } \\
\text { connection and elements }\end{array}$ & $\begin{array}{l}\text { Emphasis to sign elements } \\
\text { in some of the spots and } \\
\text { existing views. } \\
\text {. Existence of index signs } \\
\text { for visibility of the area }\end{array}$ & $\begin{array}{l}\text { Legibility and } \\
\text { imagine }\end{array}$ \\
\hline
\end{tabular}




\begin{tabular}{|c|c|c|c|c|}
\hline $\begin{array}{l}\text {.Lack of attention to } \\
\text { appropriate transport } \\
\text { with healthy and clean } \\
\text { fuel } \\
\text {.The loss of comfort and } \\
\text { convenience } \\
\text { environment due to non- } \\
\text { compliance with the } \\
\text { necessary design points } \\
\text {.Failure to meet radius } \\
\text { functional service } \\
\text { centers in the some parts } \\
\text { of the area }\end{array}$ & $\begin{array}{l}\text { The possibility of persuade } \\
\text { people to move with the bike in } \\
\text { the Texture } \\
\text {.The potential creating desirable } \\
\text { routes pedestrian and bicycle } \\
\text { The possibility of creating } \\
\text { flexibility in the area by } \\
\text { freedom of choice }\end{array}$ & $\begin{array}{l}\text {.Lack of equipment area of } \\
\text { rail transport systems. } \\
\text {.Lack of equipped bike } \\
\text {.Absence of climatic comfort } \\
\text { in the scape }\end{array}$ & $\begin{array}{l}\text {.Ability of the different } \\
\text { uses at different times in the } \\
\text { area } \\
\text {.Existence of suitable } \\
\text { safety of pedestrian against } \\
\text { cars in the area } \\
\text { Existence of multi- } \\
\text { functional buildings }\end{array}$ & $\begin{array}{l}\text { Convenience } \\
\text { and pleasant }\end{array}$ \\
\hline $\begin{array}{l}\text {.Reduction of a fabric } \\
\text { appeal and the loss of the } \\
\text { active wall due to the } \\
\text { neglect of human scale } \\
\text { in the new construction }\end{array}$ & $\begin{array}{l}\text { Opportunity to create a fabric } \\
\text { appeal by creating the } \\
\text { protrusions and troughs façades }\end{array}$ & $\begin{array}{l}\text {.Absence of appropriate } \\
\text { Flooring in the street } \\
\text {.Absence of façade building } \\
\text { with appropriate materials } \\
\text { and architectural in } \\
\text { accordance with background } \\
\text { of area } \\
\text {.Existence of visual turmoil } \\
\text { due to inconsistency in the } \\
\text { boards and building } \\
\text { extensions in the area }\end{array}$ & $\begin{array}{l}\text {.Existence of the } \\
\text { appropriate enclosed in the } \\
\text { area } \\
\text {.Existence of human scale } \\
\text { in the area } \\
\text {.Existence of Compatibility } \\
\text { form and function (visual } \\
\text { proportions) in some parts } \\
\text { of the area }\end{array}$ & $\begin{array}{l}\text { Form and } \\
\text { fabric }\end{array}$ \\
\hline $\begin{array}{l}\text { The loss of morale } \\
\text { background by new } \\
\text { construction without } \\
\text { identity } \\
\text {.Absence of codification } \\
\text { plan for locating } \\
\text { furniture in upstream } \\
\text { plan }\end{array}$ & $\begin{array}{l}\text { The opportunity of build } \\
\text { contemporary with respect for } \\
\text { tradition in the area } \\
\text { The possibility of attention to } \\
\text { texture identity in new } \\
\text { constructions } \\
\text { Opportunity of maintain } \\
\text { valuable and specific elements } \\
\text { and strengthen them }\end{array}$ & $\begin{array}{l}\text {.Absence of a memorable } \\
\text { sense in the area } \\
\text {.Absence of role motivation } \\
\text { of subjective sense in } \\
\text { meaning } \\
\text {.Lack of attention to values in } \\
\text { infill developments in the area }\end{array}$ & $\begin{array}{l}\text {.Existence of valuable and } \\
\text { important walls in the area } \\
\text {.Existence of Sense of } \\
\text { belonging in some parts of } \\
\text { the study area }\end{array}$ & $\begin{array}{c}\text { Identity and } \\
\text { differentiation }\end{array}$ \\
\hline
\end{tabular}

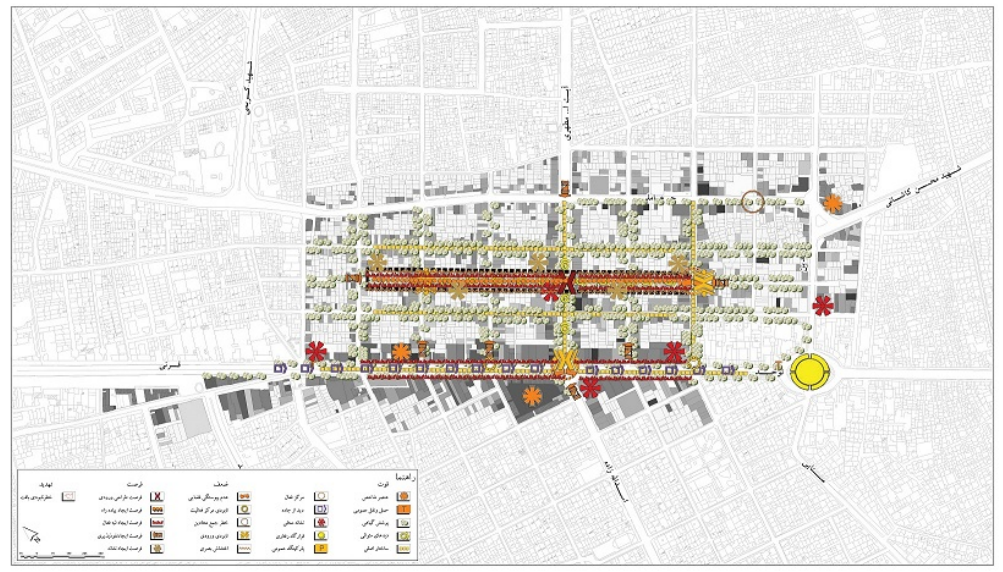

Figure 2: An integrated analysis of the study area by SWOT analysis 


\section{The Conclusion}

In the following, according to the analysis done, should be noted in order to achieve the desired goal- improving the quality of visual appeal of pedestrian-and considering limitation of financial sources of the country, it is necessary to said implementation mechanisms in the form of "urban design guidelines to improve the visual appeal”, which is as following:

\section{Vitality and dynamism}

- Establishment of active and 24hours use in dark spots and low traffic.

- Lack of establishment of use at the shaft that create the inactivity and quiescent spots.

- Use attractive population centers such as exhibitions and street theater, street cafés.

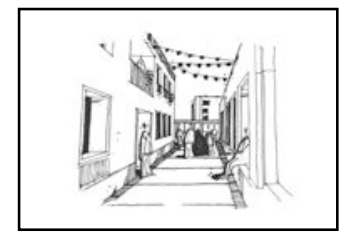

- The possibility and presence of vendors

- The high presence of people in urban space (being present citizens)

- Encourage people to move by bicycle and create the paths and equipped cycling systems.

- Existence of attractive population commercial use on the ground floor.

- placement of commercial use, leisure time and other absorber use in the central part of area.

- use innovative projects in design and implement and use of superior technology during construction and operation

\section{Vision and urban landscape}

- Creating active views through the placement of various activities on the street, being windows facing the street, balconies and increase the number of openings.

- A significant increasing the amount of lighting for public transport stations and platforms.

- The desirable landscaping with natural and artificial symbol in a way that does not distort secret space.

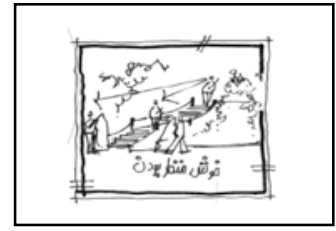

- Design and create favorable trails.

- Specify central area with consider high density and mixed-use buildings.

- Using elements such as floor line, land line and skyline.

- Visual corridor definition in relation to existing signs.

\section{Legibility and imagine}

- High legibility of area with defined the index elements and signs.

- Required continuity in brightness and lighting of area.

- Abundance of intersections and low distance between intersections.

- The small blocks of limited area design.

- Continuity walking paths from source to destination.

- Strengthen the mental elements and motive impress in sense.

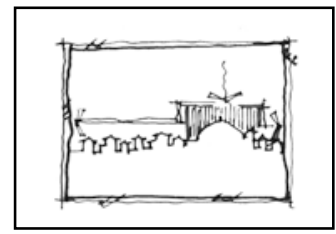


- Increase the legibility of space and ease in navigation of path.

\section{Convenience and pleasant}

- Communicate between green spaces through walk.

- Observance of equipment that follows climatic conditions and create the necessary comfort, Physically.

- Connection of limited area with other areas via public transportation systems.

- Desirable design of sit places along the walking path.

- Level space crossing with pavements.

- The use of urban furniture appropriate to the regional climate.

- Access to recreational facilities.

- Design different routes to reach a destination.

- Create a public accumulation of spaces in different parts of the

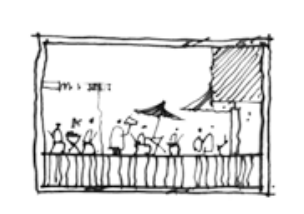
range.

\section{Form and fabric}

- The use of color and varied texture and coherent flooring.

- Preserving green space and construction of new spaces.

- Create an appropriate sense of closeness by comply the ratio of height to street width.

- Create closeness Software (trees and vegetation).

- Creating the necessary measures to comply with human scale.

- Avoid monotony environment with the wrong location street furniture.

- Development and improvement of pedestrian and their relationship with each other and the absorbent spots.

- Using simple forms and centralist.

- Recommended the use of porous surfaces to collect surface water.

\section{Identity and differentiation}

- Make a distinction between the uses and change elements of special lighting to enhance the visual appeal.

- The use of vegetation that marks the change of seasons within area.

- Existence of uses that encouraging presence, pause and engage.

- Locating the required uses are accessible on foot and bike.

- Perceptual axis values-based and location-based boost in the past.

- Strengthening of location based on perceptual axis values in the past.

- The use of vernacular architecture in harmony with the character and spirit of patterns and neighboring projects. 


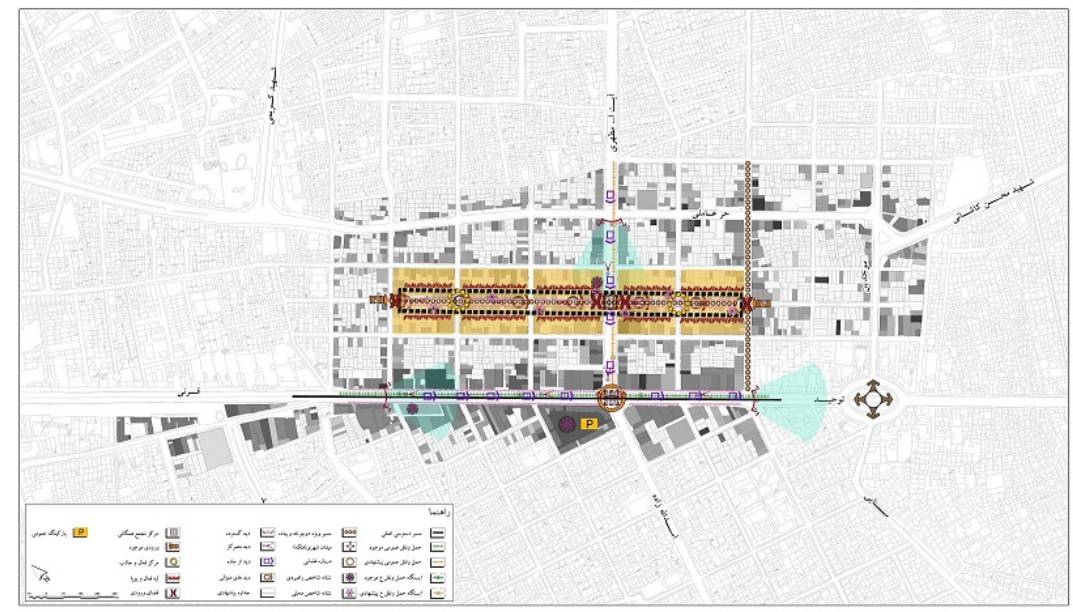

Figure 3: Urban Design Framework of study area

In this study, tried to measured and assessed one of the most important issues of contemporary urban design, the process began by study and analysis theoretical research and Literature review forming a conceptual framework to enhance the visual appeal pedestrian by examining the theories of experts and their experiences in Iran and the world. This part of studies shows that factors and characteristics presented in the mentioned model is one of the main effective criteria on improving the pedestrian environment in a area of visual appeal. The next step of research, continued with do studies Identification and measuring situation of the study area- Mashhad Monfared street. This Identification and examining by SWAT analysis in the form of integrated analysis and matrix map shows that although all mentioned factors and criteria are important but also background conditions and characteristics of the surrounding area along with them are important. Finally, according to the analysis conducted in area based on mentioned model, developed operational policies and walkability urban design framework map of Mashhad Monfared street and were presented "an urban space designing guideline to improve visual appeal of pedestrian” in the form of solutions.

\section{References}

1. Pakzad (1384), “ the urban spaces design guideline in Iran”, Payame Sima Design \& Publishing consulting, Tehran.

2. Carmona, M., T., et c, d, Tyzdal, or. (1388). "Public spaces, urban places”, Fariba Gharaei, Mahshid Shokuhi, Zahra Ahari, Esmaeil Salehi, Art University.

3. Morris, c. (1374). "The history of the town until the Industrial Revolution", Razie Alizadeh, Science and Technology Univesrsity of Iran, Tehran.

4. King, Wendy.C.; Brach, Jennifer.S.; Belle, Steven; Killingsworth, Richard; Fenton, Mark; Kriska, Andrea.M. (2003). "The Relationship between Convenience of Destinations and Walking Levels in Older Women. American Journal of Health Promotion,” 18(1), 74-82. Leslie, Eva; Saelens, Brian; Frank, Lawrence; Owen, Neville; Bauman, Adrian; Coffee, Neil; Hugo, Graeme (2005). Residents’ Perceptions of Walkability Attributes in objectively Different Neighbourhoods: a pilot study. Health \& Place, 11, 227-236. 
5. Cowan (1388), Urbanism dictionary, Yalda Belarak, Parham Naghsh Publicationa, First print, Tehran

6. Southworth,M.(2005). "Designing the Walkable City" journal of urban planning and development, vol. 131, no. 4.

7. Amid (1363), "Amid dictionary including Arabic and European words in the Persian language and scientific and literary idioms", Amir Kabir Publication. Tehran

8. Golkar (1378), "Exploring in the definition of urban design”, center of studies and research of urban planning and architecture, Tehran.

9. Cullen (1387), "Selected urban landscape", Tabibian, Tehran University Publications

10. Pakzad (1385), "Urban design theory and process ". Tehran: Shahidi Publications

11. Jan Gehl (1387)Life Between buildings, Shima Shasti, Tehran, Publications Organization Jahad Daneshgahi

12. Davies, l.(2000). Urban Design Compendium I, English Partnership, the Housing Corporation.

13. Pakzad (1388),”the urban space design guideline in iran”. Shahidi Publications, Fourth print, Tehran

14. www.CABE.com

15. The San Diego Regional Planning. (1388). "Planning and design for pedestrians, Reza Basir Mozhdehi, Tahan Publications, second Print, Tehran

16. planning and urban design standards. (1390). "Planning Association of America, places, and products". Etema, Behzadfar, Salehi and Milani, Azarakhsh Publications, First Print, Tehran

17. Biddulph, M. (2007). Introduction to residential layout, Greate Britain.

18. Mehrazan Consulting Engineers.(1391), "Detailed design review of Mashhad City Region 2". Mashhad municipality. 